\title{
Literature Review on Accounting Talent Training Mode in Application-oriented Universities*
}

\author{
Songbin Lin \\ Fuzhou University of International Studies and Trade \\ Fuzhou, China 350202
}

\author{
Yinhui Yang \\ Fuzhou University of International Studies and Trade \\ Fuzhou, China 350202
}

\begin{abstract}
A lot of researches have been done at home and abroad on the research of college accounting talents training model. The accounting talents training model is studied from the aspects of teaching direction, curriculum system, teaching methods, and faculty resources to provide high-quality accounting talents for the society. To this end, it is particularly necessary to review the research on accounting personnel training models at home and abroad.
\end{abstract}

Keywords-application-oriented universities; accounting talent training model; review

\section{INTRODUCTION}

Domestic and foreign accounting education circles have conducted many researches on accounting personnel training methods, training content, and accounting talent capacity framework. The research on the accounting talent capacity framework is mostly concentrated in foreign research. From the perspective of time span, accounting talent capacity framework research and accounting education have gone through a long period of time. Therefore, with today's rapid economic development, the study of local college accounting personnel training model is an important issue.

\section{SignifICANCE OF TRAINING MODEL FOR ACCOUNTING TALENTS IN APPLICATION-ORIENTED UNIVERSITIES}

\section{A. To Strengthen the Reform of the Accounting Professional Training Model}

At present, the accounting professional training model is no longer adapted to the requirements of the development of the market economy. On the one hand, the number of students in the accounting profession has continuously increased as colleges and universities nationwide increase the enrollment. On the other hand, the employment situation of accounting professionals is getting worse and worse. Accounting talents cannot meet the employer's demand for accounting professionals. The interaction between the two aspects has led to a structural contradiction between "quantity" and "quality" in the cultivation of accounting professionals: excess quantity and low quality of training. It

*Fund Project: It is supported by key projects of Fujian Provincial Education Science "Thirteenth Five-Year" Plan in 2017: Literature Review on Accounting Talent Cultivation Mode in Application-oriented Universities (Project Number: FJJKCGZ17-196) can be seen that the cultivation of accounting professionals has become a major channel for the delivery of accounting talents. Problems have arisen in the training mode. The accounting talents cultivated cannot meet social needs and must be reformed.

\section{B. To Provide Reference for Relevant Persons to Study Accounting Personnel Training}

There are many ways to cultivate accounting professionals. However, they are self-contained and have not yet formed a unified standard. We will systematically sort out the existing training methods for accounting professionals and strive to build a scientific and reasonable accounting professional training model on this basis.

\section{To Cultivate Accounting Professionals Who Can Meet the Needs of Society}

Economic globalization and internationalization of enterprises are inevitable trends in the development of the market economy. The future society will have a greater amount of demand for accounting professionals. This is the inevitable result of human economic and social development. Training models for accounting professionals adapt to the current economic development, and effectively provide the necessary talent for the society.

\section{DOMESTIC RESEARCH ON ACCOUNTING TALENT \\ TRAINING FOR APPLICATION-ORIENTED UNIVERSITIES}

\section{A. Research on the Concept and Components of the Training Model of Applied Talents}

Some scholars start with the "model", "training personnel", and "characteristics of the talent training model". And they scientifically define the concept of the talent cultivation model. They believe that the "personal training model" is the operation method and organizational form of the personnel training process. It consists of eight elements: talent cultivation concept, professional setting mode, curriculum setting method, teaching system, teaching organization form, implicit curriculum form, teaching management model, and education evaluation method. Some scholars also analyze the applied talent cultivation model from a theoretical perspective. This model is a clear answer to the question of "how to do and how to do it" and is a concrete operation procedure for personnel training. 


\section{B. Research on the Objectives and Orientations of Training Models for Applied Talents}

Some scholars use comparative analysis methods to compare applied talents with academic, research, and comprehensive talents to find out their similarities and differences. And they pointed out that the construction of applied talents training model should be student-centered. With the help of practical teaching, the "applicability" of the process promotes the improvement of students' professional practice ability. Some scholars also point out that the local colleges and universities are developing the guiding ideology and defining the content and method of education from the perspective of thoughts, ambition and practice. They must pay attention to the needs of local economic development. They should use practical teaching methods to build application-type personnel training model. Chen Xiangyun also believes that there are problems in the cultivation of accounting personnel, such as inaccurate training objectives, weak teacher resources, obsolete teaching contents, backward teaching methods, and disconnected teaching practice from practical operations, which seriously restricts the improvement of accounting education and the development of education.

\section{Comparative Study on Training Models of Foreign Applied Talents}

Some scholars have summarized and explained the production and development history of universities in the United States, such as the University of Cincinnati, the Massachusetts Institute of Technology, and Harvard University, in terms of time and space. Combining with China's national conditions and reference, they have refined the "Engineering and Learning Alternation" and "Undergraduate Research Program" types and the "schoolenterprise cooperation" model and other distinctive application-oriented personnel training models, . Some scholars also proceed from the connotation construction of talent cultivation. They have conducted in-depth research on the "market-oriented" talent training model in the UK, the "practical" talent cultivation model of the German University of Applied Science and Technology (FH), and the "cooperative education" talent training model in the United States. Summing up and drawing lessons from experience, this paper proposes specific and perfect strategies for the construction of applied talents training models in universities in China.

\section{Research on the Applied Talents Training Mode}

Some people point out that the cultivation of applied talents lacks practical teaching, and colleges and universities must pay attention to the construction of connotations. Others also study the imperfection of teacher training, pointing out that teachers are the key factors influencing teaching activities. And colleges and universities must strengthen the teaching staff with both scientific knowledge and professional skills. First, we must pay attention to expanding the size of teachers. Second, we must pay attention to improving the structure of teachers. There are also some scholars who have studied and summarized issues such as: unclear positioning of personnel training objectives, inaccurate updating of the concept of personnel training, diversification of teaching methods, optimization of the construction of teaching staff, lack of characteristics of professional settings, and imperfect teaching systems.

\section{E. Research on the Countermeasures for Training Modes of Applied Talents}

Some scholars use demand-oriented theory as the basis for their research. With the aid of comparative research methods, they have conducted a detailed analysis of the professional education in Germany and the professional education of "industry-study combination" in Australian universities in terms of training concepts and training objectives. And they have proposed the creation of "demandoriented" talent cultivation process. They will implement a new model of application-oriented undergraduate talent cultivation based on "demand" to improve the quality of university education and the quality of personnel training. There are also scholars who set out from a market-oriented perspective and proposed the "market mechanism-oriented" talent training model. Target formulation and process implementation must be closely linked with market mechanisms.

Some scholars also proceed from the specific aspects of teaching and put forward suggestions for improvement. Some people started from the establishment of the teaching system and put forward the construction of the applicationoriented talents training model with the production, learning, and research. Some scholars also proposed corresponding strategies for improvement in practical teaching, curriculum setting, teaching methods, and professional settings. Of course, there are also scholars who proceed from the elements of the talent cultivation model and propose specific responses. Some scholars have discussed the shortcomings of the undergraduate talent training mode from the perspectives of institutional mechanisms, faculty and training conditions. And they have proposed that universities should optimize talent cultivation models from system construction, management, and implementation. It fully realizes the "student-centered" schools, and promotes the quality of education and teaching. In view of the problem of curriculum setting in accounting teaching content, Ma Jinying said that the present arrangement of accounting curriculum and the content of course teaching in institutions of higher learning was lacking in advance consciousness. On the one hand, some courses only pay attention to the introduction of methods, lacking in-depth theoretical analysis and research. On the other hand, the lack of vivid teaching cases that are close to the actual economic work is not conducive to students' interest in learning and students' ability to analyze problems and solve problems.

Yuan Yongping believes that theoretical textbooks should highlight its "simplicity and practice" and have certain innovations in the curriculum. First, it should integrate the two prevailing "Accounting Principles" and "Corporate Accounting" textbooks into "Primary Accounting". The cancellation of the processing of "supply, production, and sales" in the course of "Accounting 
Principles" will be carried out directly in the description of each accounting element. The first part of the "Basic Accounting" course stresses the principles of accounting. The latter part deals with the accounting of the six major elements of accounting and the preparation of accounting statements. "Intermediate Accounting" describes the accounting treatment of special businesses in industrial enterprises. The second is the creative development of "industry-specific business accounting" textbooks, which integrates features-based businesses in industries other than industrial and commercial enterprises. It is required to write a separate chapter. The industry personality does not involve common content. To broaden the scope of students' knowledge would help increase the employment channels of students.

Some scholars proposed to build a new applicationoriented talent training model that aims to improve the overall quality of students with a "student-centered" approach. This model emphasizes that personnel training must start from many aspects. Much attention should be paid to the clearness of goal orientation and the specialization of professional settings. It would optimize the application of personnel training model of local colleges and universities. And then, it would provide useful advice to promote the professional skills of students.

\section{The Status QuO OF Other COUNTRIES ON THE ACCOUNTING PERSONNEL TRAINING MODEL OF COLLEGES AND UNIVERSITIES}

In foreign countries, the American Accounting Education Reform Commission (AECC) explicitly stated that the purpose of school accounting teaching is not to train students to become a professional when they graduate, but to cultivate the qualities a professional should have in the future in the "Objectives of Education for Accountants". Accounting education should teach students how to study and lay the foundation for lifelong learning. Accounting education should be a condition for students to become professional accountants. At the same time, if graduates want to become qualified accountants, they must continue to learn and have the ability to continue learning for life. Higher accounting education should teach students the learning ability needed to obtain and maintain the qualifications of a professional accountant. In other words, students should be taught how to learn. And they have the ability to acquire knowledge. It would lay the foundation for lifelong learning. "To teach people fishing skills is better than to give people the fish."

Some scholars started from the teaching influencing factors and conducted research. Some scholars start with the influence factors of talent cultivation-teachers. They would analyze the impact of teacher factors in applied undergraduate education, and point out that teachers play multiple roles in teaching activities. And they are the key factors for achieving the goal of talent training. There are also scholars elaborating the necessity of the construction of practical teaching bases in schools in many aspects. The specific requirements for the cultivation of applied talents have been pointed out in terms of skills training, discipline construction and campus culture construction. The American
Association of Colleges and Universities (abbreviated as AACSB) stipulates: "Most university teachers must have latest relevant accounting practice work experience". That is to say, university full-time teachers must have a certain degree of accounting practice in relevant fields. The students can be taught more vividly. And students can be trained in a training mode that is more suitable for market needs and social requirements. In the United States, many universities allow accounting instructors to go out for freelance jobs every week for a certain amount of time. These measures to increase the experience and practical experience of teachers and improve the business level would have great help.

Accounting education and accounting profession are interdependent. It promotes the practical ability of accounting teachers and enhances the quality of accounting education. It would cultivate high-level professional accounting personnel. And then, it would better realize accounting personnel for social and economic services. American scholar Albrecht \& Sack studied the importance of the development of skills elements in accounting education, and tried to analyze whether accounting practitioners and accounting professional teachers agree with the necessity of fostering relevant skills. Two other American accounting scholars, Francisco \& Kelly (2002) further studied the above research. They found that in the United States, accountants, accounting teachers and students have similar views on the importance of different skill factors.

After many years of research and discussion, the United States and other developed countries have formed a more consistent view on the important issue of accounting education reform. They believe that traditional single accounting education will be combined with business, management science, and other social or humanities disciplines replaced by multi-discipline education.

\section{CONCLUSION}

At present, at the stage of popularization of higher education in China, the state supports the transformation of local colleges and universities to implement applied talents training. It is precisely the new talents cultivation strategic goals that have been formulated in consideration of the socio-economic, scientific and technological development status, and current employment market demand for applied skilled talents to meet the needs of multiple parties for talent. Therefore, in the context of the transformation and development of local colleges and universities, the construction of a training model for applied undergraduates adapted to social development is not only a practical need for social and economic development, but also an objective demand for the development of higher education.

\section{REFERENCES}

[1] Yao Meijuan. Research on accounting talent cultivation mode in the "Internet+" age [J]. Business Accounting. 2017(06) 姚美娟.互联网 +”时代下的会计人才培养模式研究[J].商业会计.2017(06)

[2] Wang Kaitian. Exploration and practice of training mode for highquality accounting talents [J]. Friends of Accounting. 2018(05) 王开 田.高素质会计人才培养模式的探索和实践 [J].会计之友.2018(05) 
[3] Cai Lei. Research on the training model of undergraduate accounting talents under the international vision[J]. Modern Economic Information. 2018(01) 蔡蕾.国际视野下应用型本科会计人才培养 模式研究[J].现代经济信息.2018(01) 